\title{
Sivistyneenä uudelle vuosituhannelle?
}

Vykysuomen sanakirja selittää sivistys-sanaa viidellä palstalla ja 1 kulttuuriakin neljällä. Se osoittaa, että ilmiö, joihin sanoilla viitataan, on kielenkäytössämme ja elämässämme sekä keskeinen että hankalasti määriteltävä. Yksi selitys näkee sanat synonyymeina. Ehkä on kuitenkin turvallisempaa sanoa, että niiden referentit peittävät vain osittain toisensa. Kulttuuripolitiikkaa tehdään joka päivä, sivistyspolitiikan olemassaolo ilmiönä on jo epäilyttävämpää. Kulttuuriteollisuus täyttää tietoisuutemme, sivistysteollisuus-sana ei toivottavasti koskaan löydä tietään sanavarastoomme.

Qivistyksen sisältö ja merkitys muuttuvat ajan ja kulttuurin kehitykSen mukana. On selvää, että kansallisen heräämisen aikana sivistys koettiin korkeakulttuurina, patsaina syntyvän kansakunnan kaapin päällä. Sivistyksen funktio oli erottautuminen vallanpitäjien kulttuurista ja oman ainutlaatuisuuden todistaminen, ensin itselle ja sitten muulle maailmalle. Sivistynyt oli se, joka tunsi topeliuksensa, snellmaninsa, lönnrotinsa, runeberginsa ja kivensä sekä sisäisti heidän sanomansa. Pian tämä sivistyneistö alkoi kuitenkin etsiä juuriaan kansankulttuurista, jonka nähtiin olevan todellinen kulttuurin aarreaitta. Lukkarin koulun tai kansakoulun ylittävän muodollisen koulutuksen kohdentuminen kovin harvaan ikäluokan edustajaan teki heinäpellolla ylioppilaslakki päässä ahertavasta opiskelijasta kansan silmissä sivistyneen maisterin. Suomen kansa on aina arvostanut koulutusta sivistyksen merkkinä. Koulutuksen universaalistuminen on kuitenkin riisunut sen yltä kaiken mystiikan. Koulusivistystä saanut ei enää voi erottautua valtaväestöstä salatun tietonsa avulla. Moni pessimisti myös toteaa, että koulut ovat väärä paikka sivistyksen etsimiseen. Oppi ja sivistys ovat lakanneet kulkemasta käsi kädessä. Humboldt, Newman tai Snellman eivät tunnistaisi nykyistä yliopistoa yliopistoksi tai koulun päättymistä juhlivia nuoria kansakunnan toivoiksi.

Kovin pitkälle uudelle vuosituhannelle ei Kalevalan tai ylioppilastodistuksen varassa selviä. Yhteistä maailmankyläämme hallitseva teknologinen kulttuuri pakottaa etsimään myös uusia sivistyksen sisältöjä ja uusia majakoita, joiden varassa suunnistaa. Mutta jos sivistyksen sisältö ja kohteet muuttuvatkin, pysyykö sen olemus samana? 
Onko sivistys enemmänkin asenne ja näkökulma todellisuuteen kuin sivistyskohteiden identifiointia?

1 itä sivistys minulle merkitsee? Se merkitsee ehjää elämänkatsonen. Se ei kuitenkaan merkitse silmälappuisuutta tai fanaattisuutta omien arvojen puolesta. Sivistynyt on suvaitsevainen. Humanisti tarvitsee matemaattisen tai luonnontieteellisen perussivistyksen ymmärtääkseen teknistä kulttuuriamme. Insinöörin puolestaan tulee ymmärtää sitä yhteiskuntaa ja niitä ihmisiä, joita varten hän suunnittelee tekniikkaansa. Oman kreikkalais-juutalais-roomalais-kristillisen perintömme tunteminen lisää mahdollisuuksiamme ymmärtää nykyEurooppaa ja kulttuurimme muutosta. Uskonto opastaa meitä moraaliseen ja eettiseen kypsyyteen. Tästä näkökulmasta kovin huolestuttava onkin suuntaus, jossa täydennyskoulutuksen lähes ainoaksi tehtäväksi on muodostunut ahdas oman peruskoulutusalan erikoistumisen lisääminen. Sivistyksen näkökulmasta tarvitsisimme ristiinkoulutusta, uusien alueiden valtausta ja uusien näköalojen etsimistä, ymmärryksemme laajentamista. Uskaltaisiko sanoa vapaata sivistystyötä!

Kirjailijat, kuvataiteilijat ja musiikin tekijät tulkitsevat meille oivaltaen ja syvällisesti jaettuja kokemuksiamme sekä avartavat kokemuksemme piiriä. Usein he toimivat myös yhteiskunnan omatuntona. Persoonallinen suhde heidän luomuksiinsa on sivistystä. Aikamme arvostaa välineellistä informaatiota ja tietoa. Sen hankinnan systematisointiin muodollinen koulutus on omiaan. Tie sivistyneeksi ihmiseksi alkaa kuitenkin vasta, kun tieto on jalostunut ymmärrykseksi ja ymmärrys viisaudeksi.

B enjamin Disraeli sanoi sata viisikymmentä vuotta sitten, että lisivistäjää. Sanat ovat totta edelleenkin. Korkeampi hengenviljely harvoin viihtyy aineellisessa kurjuudessa. Tarvehierarkiat opettavat, että fyysiset perustarpeemme tulee tyydyttää, ennen kuin henkiset tarpeet voivat tulla tyydytetyiksi. Toimeentulohuolista vapaa aika antaa meille tilaa irtautua instrumentalismista, vain sen tekemisestä, josta on välitön hyöty. Aito sivistys on itseisarvosta.

Reijo Raivola 